Una semblanza de Virginia Morán

Mario Giorgi

Question/Cuestión, Vol. 2, №66, Agosto 2020

ISSN 1669-6581

https://perio.unlp.edu.ar/ojs/index.php/question/index

IICom-FPyCS-UNLP

\title{
UNA SEMBLANZA DE VIRGINIA MORÁN
}

\section{A STORIE ABOUT VIRGINIA MORÁN}

\section{Loc. Mario Giorgi}

Director de Medios de la Universidad Nacional de Avellaneda y Conductor del programa Llega el Día por Radio Nacional AM 870

mgiorgi@undav.edu.ar

\section{Resumen}

Virginia Morán, locutora y actriz de larga trayectoria en el ámbito cultural de la ciudad de La Plata. Fue poseedora de una voz singular e inolvidable, al igual que su generosidad y solidaridad. Comprometida con los mejores contenidos de poesía y relatos breves de autores argentinos, latinoamericanos y españoles. Una forma de conducción irrepetible, pausada, calma y profunda. La recuerda, Mario Giorgi. 


\title{
Palabras clave
}

Radio, Conducción, Locutora, Cultura

\begin{abstract}
Virginia Morán, broadcaster and actress with a long career in the cultural field of the city of La Plata. She was the possessor of a unique and unforgettable voice, as well as her generosity and solidarity. Committed to the best poetry content and short stories by Argentine, Latin American and Spanish authors. An unrepeatable, slow, calm and deep way of driving. Remember her, Mario Giorgi.
\end{abstract}

\section{Keywords}

Radio, Conducting, Announcer, Culture

\section{Enlace}

https://go.ivoox.com/rf/55781855 